\title{
ROSA PRAED AND THE VAMPIRE-AESTHETE
}

\author{
By Andrew McCann
}

Rosa CAMPBell PRAED left Australia for London in 1876. In the decade or so subsequent to her arrival in the metropolis she forged a successful career as a writer of occult-inspired novels that drew on both theosophical doctrine and a nineteenth-century tradition of popular fiction that included Edward Bulwer-Lytton and Joseph Sheridan Le Fanu. A string of novels published in the 1880s and the early 1890s, including Nadine: the Study of a Woman (1882), Affinities: A Romance of Today (1885), The Brother of the Shadow: A Mystery of Today (1886), and The Soul of Countess Adrian: A Romance (1891), produced a sort of popular aestheticism that melded an interest in fashionable society, a market-oriented Gothicism, and speculations on the philosophy of art that were indicative of Praed's relationship to a fin-de-siècle Bohemia and its literary circles. There is no doubt that these novels can be located in terms of the numerous popular genres - the art novel, the aesthetic novel, the occult novel $^{1}$ - that form the literary background to much better known texts such as Oscar Wilde's The Picture of Dorian Gray, Bram Stoker's Dracula and George du Maurier's Trilby. But to account for Praed's ephemerality in terms of a series of generic categories elides too easily the pressures - economic, political, and aesthetic - impinging on a colonial, female novelist quickly forging a career at the centre of an imperial culture. Praed's novels are hybrid, polysemic creations, over-determined by these pressures, which in turn, no doubt, have contributed to her invisibility in contemporary literary studies. Their Gothicism and their appropriation of theosophical doctrine are both manifest in themes like mesmerism, telepathy, duel personality, and the recurring figure of the spiritual or "moral vampire." Yet these obviously commercial novels are also intensely invested in aesthetic questions, in the dislocated character of imperial experience, in the accrual of cultural capital, and in their own relationship to the vexed question of their originality vis-à-vis the market for popular fiction.

In this essay I want to think about the ways in which Praed's occult-inspired novels deploy the figure of the vampire-aesthete, at the centre of both Affinities and The Soul of Countess Adrian, to introduce a self-reflexive relationship to the different economies of value in which they were embedded. In suggesting that Praed's vampire-aesthetes articulate anxieties about cultural value and influence in an imperial economy, I also want to diversify the provenance of the fin-de-siècle vampire. Recent work on late nineteenth-century aestheticism has persuasively discussed the semiotic force of the vampire in regard to questions of sexual identity. Robert Dixon, one of the few critics to engage with Praed's occult fiction and to locate it in terms of its relationship to better known writers like Bram Stoker, reads her interest 
in vampirism in terms of the fissures and conflicts inherent in gendered subjectivity (10017). This version of the vampire takes on a more specific and emphatic meaning when it is related to the question of queer identity, and what Richard Dellamora calls the "gaying" of late nineteenth-century literary studies (1). Talia Schaffer's 1994 discussion of Dracula as a novel obsessed with Oscar Wilde, his homosexuality, his trial, and his subsequent vilification, has consolidated a sense of the vampire as an intensely ambiguous avatar of homosexual desire by contextualising Stoker's version of it in terms of his (effaced) homoerotic relationship with Wilde (see "A Wilde Desire Took Me"). Her argument that Stoker's Count is Wilde refigured as an abject, effeminate monstrosity is so compelling, and so thoroughly supported by careful archival research, that it also has the effect of attributing the genesis of the vampire-aesthete exclusively to the cauldron of repression, concealment, and recoding that Schaffer maps through these two very canonical figures. ${ }^{2}$ Schaffer's argument, however, is both consolidated and complicated by the fact that Dracula was not the first novel to present Oscar Wilde in the guise of a vampire. Praed's Affinities, published twelve years before Dracula, is centered around such an unmistakable portrait of Oscar Wilde as a "moral vampire" that the novel's publisher, George Bentley, objected to its explicitness: "You have no right to draw a portrait so like Oscar Wilde that the public at once identify him, and then make this man do anything which society would condemn him for," he wrote to Praed in 1885. The letter goes on to suggest that Praed might "do what the press does in regard to him," but that she must "stop short of anything which could throw a shadow of doubt on his moral character, or his rectitude." 3

Needless to say, Praed's own ambiguous sexuality invites us to read her novels and her interest in Wilde as yet more evidence for an already convincing argument about the way in which the vampire functions as both an evocation and a denunciation of queer identity. The details both of Praed's life and her fiction undeniably situate her in what Damien Barlow calls a "tradition of Victorian lesbian cultural production" (346). As Barlow has argued, scholarship on Praed has tended to be dominated by an elision of her occult fictions and especially her interest in channelled writing, which emerged out of her relationship with Nancy Harward, a trance-medium with whom she lived for twenty-eight years. This elision, Barlow suggests, has also amounted to a repression of the same-sex desire, often troped as spiritual intercourse, that clearly informs so many of Praed's novels. According to Kay Ferres, Praed's occult-inspired texts are productive precisely because they muster a theosophical notion of the relationship between the physical and the spiritual in order to launch a critique of heterosexual identity and object choice (249). These arguments about the relationship between the occult and queer sexuality are convincing, and significantly contribute to a broadening of our sense of the relationship between fin-de-siècle culture and same-sex desire. The figure of the vampire-aesthete in Praed's work, however, is a more over-determined figure than these arguments suggest. It indexes a complex and ambiguous engagement with questions of cultural influence, aesthetic autonomy, market value, and celebrity in an imperial cultural context that Praed was perhaps uniquely positioned to gauge. That aestheticism itself might merge as a form of vampiric influence, with a figure like Wilde at its centre, points to some of the valances that the circulation of cultural capital might have when it is contextualized in terms of the hierarchies structuring the relationship between the imperial metropolis and the settler-colonies of nineteenth-century Australia. Praed's work, in fact, bears out the argument that Nicholas Daly has recently made regarding late-Victorian and Edwardian romance: far from being merely a symptom of an empire in crisis or imminent 
collapse - its notions of race and gender assailed both from within and without - the apparent Gothicism of what Daly calls "popular middle-class fiction" (7) in the period also embodies an attempt to accommodate and reflect upon aspects of cultural modernization (consumerism, professionalism, globalisation, for example) in a broad imperial context (see Daly 24-29). Praed's version of the vampire-aesthete, I want to argue, overwrites the issue of sexuality with an interest in the materiality of cultural production and the regimes of value that bear upon it. Her foregrounding of anxieties around the imperial distribution of cultural capital in Affinities is developed into an implicit critique of aestheticism's commodity-character in The Soul of Countess Adrian, in which the vampire-aesthete embodies the intensely undecidable relationship between culture and commerce that is also literalized in the relationship between Praed's fiction and its potential publics.

Praed's interest in the relationship between culture and vampiric possession finds its most extensive and complex treatment in Affinities, which presents a portrait of Oscar Wilde in the guise of the psychic, or "moral vampire." Here Praed treats Wilde's aestheticism itself as a form of possession, and also gives us a sense of how a colonial writer in the midst of Wilde's milieu might have felt on beholding the deployment of cultural capital going on around her. Praed moved in aestheticist circles. She knew Lady Wilde and regularly attended her Chelsea salons, which put her in direct contact with Wilde, Stoker and a host of other prominent literary figures (see Clarke 84 and Dixon 101). Her fiction quite clearly draws on this milieu and is fascinated by the ways in which cultural celebrity was performed and bestowed in it. The plot of Affinities, which unfolds against this sort of background, is based on the triangulated relationship between the straight male suitor, the mentally impressionable, potentially inspired heroine, and the vampiric interloper. Major Graysett will fall in love with Judith Fountain, only to see her whisked off, mesmerised, and possessed by the poet-cumsorcerer, Esmé Colquhoun, recently returned from an American tour. The novel's interest for the contemporary critic stems firstly from the fact that it is a roman à clef: Esmé, the figure at its centre, is clearly meant to evoke the celebrity and the fashionable aestheticism of Oscar Wilde. ${ }^{4}$ Elsewhere in the novel we find portraits of the artist Louise Jopling and of Helena Blavatsky, both of whom Praed knew. Praed evidently changed her portrait of Wilde, making it more physically flattering, no doubt in accordance with Bentley's anxieties regarding it. Esmé Colquhoun has "a statuesque head," a throat "like a column," and lips "of the Greek type, cut in firm, sensuous lines." His "mass of red gold hair was brushed back from the forehead, and fell in thick waves to the coat behind" (110). Even in the opening pages of the novel, in which Major Graysett experiences a vision that encapsulates its entire plot, Esmé is also a figure of menace. Later, Judith describes his weirdly mesmeric effect on her as "a kind of eerie, excited sensation, like being galvanized, or as if electricity instead of blood were running through one's veins" (93). Suggestions of some sort of vampiric agency informing his hold on her are confirmed partly by Esmé himself, who introduces the idea of a "moral vampire": "a human being with the power of absorbing into his own system all the vitality and will-force of anyone peculiarly susceptible to magnetic influence, till the poor creature lost all individuality, and became a mere shell, galvanized into obedience by the will of its destroyer" (173). Esmé's hold over Judith seems to literalise this. As his wife, Graysett imagines, her "body was being worn away by some wasting disease or mental care" (224). With the aid of Madame Tamvaco, who is based on Helena Blavatsky, Graysett begins to unravel the occult forces binding Judith to Esmé. The opportunism behind the marriage is revealed, however, too late to save Judith from her husband's festering hatred. 
When Esmé realizes that the decadent artist Christine Borlase, the Louise Jopling figure and the true object of his "grosser love," will resist his mesmeric power, he wills death upon Judith, in a fit of resentment, by focusing his enmity on her painted portrait. Eyes "dilated and darkened," he transforms himself into a "magnificent fiend," launching his "murderous will" at the image (316). Judith's actual death at the novel's conclusion is accompanied by the ghostly outline of Esmé, whose power, at least here, has apparently been triumphant.

What is, superficially, a novel with a structure very similar to that of Dracula is made much more complex by virtue of its self-conscious relationship to the culture of late nineteenth-century decadence. Esmé's vampiric power is related to his literary tastes, to which Praed returns several times. He is a "disciple of Thèophile Gautier" and "the French School" (92), and at one point launches into a long defence of Gautier and Baudelaire, declaring that "the age is corrupt," that human beings have been "refined from field flowers to exotics" and that "nature is not for them."

\footnotetext{
Life is morbid. The reign of healthy melodrama is over: the reign of analysis has commenced. We make dramas of our sensations, not of our actions. Emotion has become a fine art which the artist must practice if he aim at fidelity to his creed. Life is for him a many-sided prism, in every facet of which he sees the reflection of a different phase of his own being. He lives, to feel. He feels, to reproduce; and when he has reproduced, he closes the door upon his experience. The past is shut out, and the world is the richer. He has been dowered by the gods with forgetfulness. He moves on - to receive again, and again to give forth. (187-88)
}

The egotism of this speech is given a more sinister aspect a little later when Esmé insists he is "a poet of night - the night of city and salon - luxuriously illuminated, full of passionate sweetness, suffused with the voluptuous odour of perfumes" (189). Towards the novel's climax Christine Borlase describes this sensibility as part of Esmé's corrupting power, clarifying the relationship between decadent writing, possession and a certain type of imaginative reproductivity once she has resolved to resist his power:

I deceived myself. In that unseen world there was for me - nothing - nothing but the wicked thoughts, the foul imaginations, which were born of me, and which took shape there and became devils to torment me.... They were our children - his and mine; the offspring of our minds - mine diseased, and uniting itself with the evil in him..... For you don't know - the bad things which had lain as it were, germinating - the books I had read - there was no one to mind what I read. They were there, though I hadn't understood them quite, working in me, poisoning all my thoughts and making me wicked. (264)

This explanation frames the seductiveness of Wilde's aestheticism and its more extreme French precedents as a form of perversity related to the pathologies of the over-excited imagination. It is evocative of a broader middle-class response to the culture of decadence as Wilde embodied it. The charges of immorality levelled against The Picture of Dorian Gray have been well documented: "a tale spawned from the leprous literature of the French Décadents," complained the Daily Chronicle (qtd in Mason 65-66). Praed's critique also anticipates the way in which Stoker, driven by the Wilde trial according to Schaffer, will stigmatize decadent culture as an improper incitement to imaginative excess capable of winning over, of possessing, its victims: "No one has power to stop the workings of imagination, not even the individual whose sensoria afford its source . . . individual discretion 
is the first line of defence against such evils as may come from imagination - itself pure, a process of thought, working unintentionally with impure or dangerous material" ("The Censorship of Fiction," qtd. in Schaffer, "A Wilde Desire Took Me" 389).

One could read Praed's commentary on decadence as moralising designed to appeal to a readership more conservative than the milieu captured in the novel. Indeed the orientation of the reader's sympathies towards Graysett indicates the way in which this sort of novel Marie Corelli's Wormwood: A Drama of Paris (1890) does something very similar obsessively rehearses decadent tropes in order to displace them. Praed explores a morally dangerous decadence with which she is clearly fascinated, while simultaneously distancing herself and her readers from it. The degree to which this hedging indicates an anxiety about her own sexual identity is open, and no doubt compatible with the dynamics of disclosure that might inform a Lesbian poetics in the period. What is unmistakable in the novel's take on decadence, however, is its colonial slant, which complicates both these readings. When Esmé explains that he is a poet of night, he does so to an Australian, Mrs Bearfield, who has turned up in London in search of cultural capital and apparently concluded that "a little aestheticism would counteract the utilitarian tendencies out there" (178). As Mrs Bearfield encounters Esmé she is mocked by a caustic old Admiral because she "hasn't the courage of her ignorance" (186). Put off by her pretensions, the Admiral launches into an anti-Australian diatribe.

\footnotetext{
If she would but be natural, and perhaps talk a little colonial slang, she might succeed; but that's where they all make the mistake. It's only the American who is clever enough to grasp the situation. This one hadn't sense enough to come out in the white frock and straw hat she used to wear in her garden at Geelong, and pose as the innocent barbarian. With that rose-leaf complexion she might have carried everything before her. But she tries to be modern and civilized, and European, and is as much out of place as Mrs John Wood would be in a refined tragedy. That pink satin dress with the black tarantulas sprawling over it gives me the creeps. She over-dresses. It's the way with the Australians; they have not learned yet how to put their clothes on ... we don't require Esmé Colquhoun to tell us that the age is corrupt. Surely we can see that for ourselves. (186)
}

After Esmé goes on to describe the death of nature in modern society, Mrs Bearfield responds by declaring that "we are quite out of it in Australia... We are all Nature. We are dreadfully glaring" (188). "You will strike your own note," he responds, launching into his "poet of night" speech, but adding that "an Australian Walt Whitman may perhaps lift you to a higher level than mine" (189).

For a colonial reader this is a charged encounter. Not only is decadent aestheticism morally dangerous in this novel - a form of cultural influence that Praed literalises in the moral vampire - it is also a way of embodying cultural capital and distinction that has the effect of binding the colonies into a degrading metropolitan hierarchy. This hierarchy tends towards the elision of a colonial experience that cannot possibly be adapted to the cultural norms of a leisured class confident in its ability to define the "spirit of the age." In such circumstance an Australian Walt Whitman looks remote, to say the least, doubly so given the sense of "Whitman" functioning as a code for homoerotic fraternity. Seen in its broad imperial context, the culture Esmé embodies has something metaphorically vampiric about it in that it empties out colonial subjectivity and demands an abject deference to metropolitan norms that stifle its articulation. That Praed took this issue very seriously is evident in 
her continued and increasingly fervent interest in Australia and her own Australianness. Enthused by a return trip at the end of 1894, her autobiographical My Australian Girlhood (1902) and her novel Fugitive Anne (1902) both adapt theosophical themes to Australian landscapes and at least implicitly link them to the animism of Indigenous Australian belief systems. These texts can be read as direct responses to metropolitan aestheticism, in that they attempt to reformulate colonial experience in a manner that can appropriate both the occult and aesthetic preoccupations of the London literary circles in which Praed moved, while refusing the aestheticist disdain for nature. Hence Praed's Australian heroines and her authorial voice increasingly manifest a kind of primitivism that seems to respond to Esmé Colquhoun very directly. Praed's My Australian Girlhood opens with a refusal of "smug English conventionalities" that will become typical of the way in which she adapts Australian material to the fashionable genre of occult fiction after the nominal demise of the aesthetic novel in the late 1890s: "after thirty years of civilised existence, that wild youth 'down under' comes back to me in all its unforgettable charm, and I am grateful to it for having brought to bear on my life at least one mighty influence - one passion from whose thrall I have never wished to escape. My Australian girlhood taught me to love Nature, and to find in the old Nurse ever my best friend" (1).

The Soul of Countess Adrian, perhaps Praed's neatest version of the vampire-plot, is fascinating in the light of the anxieties about cultural and moral influence expressed in Affinities, because it shifts Praed's occult fiction towards a clearer sense of the relationship between aesthetic distinction and cultural commerce, and thus begins to demystify aestheticism by drawing attention to its contradictions. The novel is set against a vision of the public in which these contradictions are reflected. This public, frequently referred to as Bohemian, is simultaneously refined and vulgar, invested in the intellectual trappings of late nineteenth-century aestheticism, yet also laughably superficial, a prey to the whims of fashion. It is a leisured public consolidated around the theatre, urban salons and country estates. Praed's evocations of it betray a complex sense of how these informal social institutions assumed a disdainful distance from commercial activity, even though they also constituted the market of consumers towards which an aspiring writer like Praed was pitching herself. These tensions are implicit in many of Praed's novels, but in The Soul of Countess Adrian they are evoked very directly. Mrs Walcot Valbry's drawing-room, early in the novel, is a representative example of the sort of social space with which Praed's fiction is obsessed:

\footnotetext{
The cultivation of cheap celebrity is a disease in upper Bohemia, where patrons and patronised, inviters and invitees, have their very being, socially and commercially, in the easily bought advertisement which sells their wares and trumpets them into a third-rate notoriety. Mrs Walcot Valbry was rich enough to despise paragraphists; nevertheless, paragraphists abounded at her "at Home;" and representative Bohemia - mummers, novelists, poets, artists, dilettanti members of parliament, and sensation-hunting visitants from a more aristocratic sphere, made a brave show in the spacious drawing-rooms. Just outside the most prominent door, Mrs Walcot Valbry herself, large, bediamonded, with the crisp, abundant white hair and yellow crumpled face familiar to the casual traveller in the parlours of New York hotels, stood, and in an absent manner received her guests. (26-27)
}

This sort of passage represents a development in the clarity of Praed's view of metropolitan literary culture. It intimates what will become increasingly apparent in the novel itself; the 
covert investment of aesthetic autonomy - the l'art pour l'art that Esmé derives from Gautier and that Praed refigures as a kind of enchantment - in the forms of commercialisation that, at least superficially, the "aesthetic disposition"5 seems to refuse.

Against the satirically evoked backdrop of "upper Bohemia," The Soul of Countess Adrian plays out a plot built around the metaphysical concerns of both aestheticism and the occult. The novel opens with Beatrice Brett, an actress, a "celebrated American "Improvisatrice", (25), en route to London. Bernard Lendon, a Chelsea-based artist, is already falling for her on the trans-Altantic crossing. Once in London, however, the possibility of a blossoming romance is undermined by the sinister appearance of the society femme fatale Countess Agnes Adrian, a devotee of Théophile Gautier's Avatar, who will fall in love with Lendon herself. Thwarted by the artist's love for Beatrice, the Countess, or at least her soul, takes possession of Beatrice and infuses a vulgar carnality into the hitherto innocent body of the young actress. As the Countess declares that her bridal gift will be her own spirit, she proceeds to seal the transfer of souls with a typically Gothic kiss:

The red lips of Countess Adrian bent down to Beatrice's lips and clung to them in a vampire kiss which seemed to drain the very life-breath from the girl's body. She uttered no sound, but as Countess Adrian moved from her she sank white and limp into Lendon's arms. Countess Adrian stood for a moment, rigid, and with staring glassy eyes. Then, with a sudden piercing cry, she pressed her hand to her heart, her body swayed and she fell upon the floor. (166)

Beatrice's performances of the Duchess of Malfi, hitherto applauded for their exquisite sensibility, now take on an "unsexed air as of a coquette" (178). They lose their aura of purity and take on the "recklessness of passion," "the embodied lust of the flesh" (179). Things are put right when the famous occult practitioner Maddox Challis shows up to perform a climactic exorcism and explain the doctrine of "vampire spirits," which turn out to be "the astral corpses of those who have died in crime or in the flush and heat of sensuous longing, and who, bodiless, tormented by desire, and incapable of gratifying it, haunt cities, like vampires suck the vitality of human beings, and even sometimes enter the bodies of living persons, and thus live on in enjoyment of their material pleasures" (190).

The ideas of possession and metempsychosis raised here are also introduced earlier in the novel. In the opening pages of the text they clearly foreshadow occult themes, but here they also have a much more direct relationship to Praed's own occult-inflected version of aestheticism. During the voyage to London, Beatrice outlines to Lendon the metaphysics underpinning her view of great art. "Art is the door through which the undying dead ones can come into our lives and teach us how to move our world as they themselves once moved theirs," she explains. "If ever I am a great actress," she continues, "as indeed I think I shall be some day, it will not be I myself who have any power, but the ghosts who have given to me of theirs" (19). This theory of morbid inspiration is shared by Beatrice's uncle, who explains to Lendon that his niece has "the unconscious power of access to the highest influence of the past - a power as rare as are the Talmas and the Siddons themselves": "It's the open door through which these bodiless beings from the other side can enter into our world again - the body by which they can vent their unsatisfied cravings and pent-up aspirations" (43).

Of course the conceit of the novel is that this account of artistic genius will be literalised in the idea of vampiric possession as the story's Gothicism becomes increasingly overt, and sensibility gives way to carnality. In the meantime, Praed's occult-inspired view of artistic 
inspiration is not as eccentric as it might at first seem. In fact the idea of the modern work of art as a moment of enchantment in an otherwise secular, rational world, as a sort of atavistic revenant of animistic magic and spirit belief, informs some of the most authoritative statements of modern aesthetic theory we have. In Dialectic of Enlightenment, for instance, Adorno and Horkheimer, developing comments made by Freud in Totem and Taboo, insist that the modern artwork's power is bound up with its ability to retain the "magic inheritance": "Just as in the ceremony the magician first of all marked out the limits of the area where the sacred powers were to come into play, so every work of art describes its own circumference which closes it off from actuality" (19). Adorno and Horkheimer help us to grasp the historical paradox of nineteenth-century fiction written under the sign of the occult. The apparently anachronistic valence of the occult vis-à-vis the processes of enlightenment is the key to its contemporary relevance. The sense of the occult as simply arcane is wrong in at least one important way. In The Soul of Countess Adrian, the modernity of Praed's aestheticism consists in the literalisation of spiritualist concerns as the basis of a statement about contemporary art's status and claim to distinction: the work of art lays claim to a sense of enchantment as the thing that helps it distinguish itself from other aspects of social production. Hence Maddox Challis's description of Beatrice as a Sybil claims a quasi-sacred quality for the aspiring actress (49-50). We get a sense of the modernity of the occult in Praed's use of subtitles to stress the sense that her narratives have an up-to-the-minute relevance to their cultural habitus: Affinities: a Romance of Today, or The Brother of the Shadow: A Mystery of Today. The occult, in other words, underpins an implicit and very contemporary claim to cultural distinction, in which the semblance of enchantment is juxtaposed to a vulgar, profane universe characterised by the merely commercial, and the merely empirical.

Without this sense of enchantment, without the aura of alterity, the mountains of tastefully arranged bric-a-brac that clutter the drawing-rooms and artist's studios of Praed's novels would be merely the misconstrued offshoots of a degraded commodity-culture, just as Adorno noted of the "crude accumulation" in The Picture of Dorian Gray, where the "interiors of a chic aestheticism resemble smart antique shops and auction halls and thus the commercial world Wilde ostensibly disdained" (Aesthetic Theory 16). Needless to say, the literalization of the notion of enchantment in a sensational plot about vampiric possession, full of swooning, fainting, and a carnality lingering just beyond the surfaces of all those lavishly decorated finde-siècle interiors, also undermines any claim about aesthetic autonomy from the market and the economic pressures on purveyors of popular, sensational fiction. By this reckoning the stress on the contemporary in Praed's subtitles is merely a play at hackneyed fashionability, the "cheap celebrity" of "upper Bohemia." Indeed the publication of these texts as onevolume editions - in some cases almost novellas - indicates their participation in a new stage in the commercialisation and consumability of popular fiction. The days of the threevolume novel were just about gone. ${ }^{6}$ Praed's fiction is abrasively modern in the ease with which it adopted new forms of production and circulation that relocated reading away from sequestered domestic spaces and into highly motile, interstitial spaces emerging out of developments in transport, tourism and middle-class leisure increasingly functionalised by its relationship to the discipline of the workplace (Praed's 1899 Madam Izàn is in fact subtitled "A Tourist Story"). What The Soul of Countess Adrian introduces as a claim about artistic inspiration and autonomy, in other words, also introduces the most overt signs of the novel's assimilation into the marketplace. This is partly what makes Praed's popular aestheticism so interesting. The Soul of Countess Adrian toys with the idea of aesthetic 
distinction cohering in a culture of spiritually inspired artists and Bohemians for just as long as it takes the novel to establish this as the basis of a popular sensation plot. The idea of the work of art as occult-inspired enchantment is already a mask for the commodity, and a strategy for its mystification.

The Countess as vampire-aesthete is the figure that organises the novel around an apparent tension between the imperatives of aesthetic distinction and the imperatives of commercial viability. She also consolidates this tension around an excavation of the sexual perversity that is readable at exactly the moment that the vampire and the aesthete intersect; the point at which culture reveals its "grosser" quality as a form of both sexual and intellectual possession, and a vulgar carnality shows itself to be latent within a disinterested aesthetic sensibility. This is also, needless to say, the paradox of Esmé Colquhoun: his claim to aesthetic distinction as poet-cum-sorcerer is also the basis on which Praed's novel can make a far more populist pitch at the market. The interest of both novels in aestheticist discourse, in other words, also masks (transparently) the more pragmatic, commercial pressures to which they were responding. It is as if the utilitarian spirit of Mrs Bearfield's colonies surreptitiously repossesses the centre with a sense of the professionalism and the commercial pragmatism that belies the self-image of the aesthete and his/her sensibility. In this sense Praed's writing clarifies the contradiction that is central to aestheticism and its claims to aesthetic detachment.

In Idylls of the Marketplace: Oscar Wilde and the Victorian Public, Regenia Gagnier convincingly argues that the conflation of aestheticism with notions of aesthetic autonomy inherited from the Frankfurt School elides the extent to which Wilde's aestheticism was determined by and engaged with "the emerging service and consumerist economy" (5) of late-Victorian England. Her study locates aestheticism in terms of cultural commercialisation and suggests the way in which Wilde's celebrity oriented itself towards this. As Gagnier points out, the dandy was, from the outset, central to the "fashionable novels" published by Henry Colburn in the 1820s (72-75). It was always, in other words, an avatar of literary commerce. Gagnier introduces her argument as a refinement of Adorno's thinking on aesthetic autonomy, though it in fact echoes Adorno's critique of aestheticism in Aesthetic Theory, where he draws attention to the commodity-character of aestheticist culture. Adorno believed that the works of l'art pour l'art could never survive "their latent commodity form" (237) and saw Wilde and other decadent figures as "preludes to the culture industry" (239). ${ }^{7}$ From this perspective, aestheticism, particularly by the 1890 s, would be the point at which a sense of the collusion between art and the commodity enters public discourse in the form of an openly parodic assertion of an opposition that has become unsustainable.

Praed's vampire-aesthetes bear out, in a very direct and tangible way, this reading of aestheticism. The sense that art's aesthetic value consists in its separation from other spheres of social production is literalized in the vampire's unaccountability, its enchanted aura, which in turn becomes the crux of a commercial sensation plot which, amidst an excess of sentimental cliché, is always reinvested with the kind of moral framework that suggests a reorientation of aestheticism away from an avant-garde and back towards a middle-class readership congruent with the sort of journalism that would condemn Wilde's work and ultimately Wilde himself. Praed's occult novels embody exactly the moment that aestheticism and commodified kitsch become interchangeable, while still preserving each of these points as readable components of a wished-for opposition that guarantees the reader's awareness of the hierarchies that have in fact become impossible. As Kathy Alexis Psomiades points out, aestheticism made "its own institutional nature its content" (32). Psomiades 
orients this comment toward the status of the feminine in aestheticism, which she reads as a concentration of the contradiction inherent in aesthetic autonomy. The conflict between Beatrice, as the embodiment of the aesthetic, and Countess Adrian, as the embodiment of a debased, sensational carnality, seems to embody this. Yet there is another, perhaps more fundamental sense in which Praed's novels draw attention to their "institutional nature." The vampire-aesthete is a hybrid that actually internalises the conflicts played out, superficially, between Beatrice and the Countess. It simultaneously suggests distance from and capitulation to the market. It is an opportunity to rehearse the discourse of aesthetic autonomy and a trope in a popular, sensation-driven plot that reveals the increasingly commercial orientation of the aesthetic novel. Given this sense of Praed's novels enacting the fiction of pure aesthetic detachment, it is perhaps no coincidence that Ouida, hitherto confident in the genre of the aesthetic novel, implicitly accused her of writing out of purely commercial motives (see Clarke 112). A decade later, at the close of the century, Ouida's own fiction, as Schaffer points out, displays an exhausted cynicism at the "voracious connoisseurship and unthinking commodity fetishism" of an aestheticist culture now emphatically bereft of its redeeming aura (see Schaffer Forgotten Female Aesthetes 151).

The question of literary commerce is taken up very directly by Praed's 1903 novel The Ghost. In a blatant piece not of misreading, but of non-reading, the Sydney Bulletin's Red Page (27 June 1903) dismissed the novel and its author in a sentence: "we have ceased to take Mrs Praed seriously." No doubt the novel's title suggested yet another sensational, occult-inspired text mired in an ambiguous aestheticism bordering on the prurient. The Ghost, however, is one of Praed's most secular texts, the ghost of the title being entirely metaphorical. It is a novel about cultural capital in a cosmopolitan, imperial culture and about the ownership of literary texts in that context. In it what was troped in the occult novels - the text as commodity - is dealt with directly. The novel opens in a remote country town in outback Queensland. The beautiful Adela Vaughan is introduced as an "Anglo-maniac" (4) eager to escape the colonies at any cost and repulsed by the vulgar habits of settler culture. A marriage of opportunity to the scion of a dissipated aristocratic family is her ticket to London, but her husband, Claude Goring, dies en route, leaving her to fend for herself in the metropolis. Before she leaves Australia, however, the devoted and heart-broken Horace Fayle, who has descended from Rugby School and Cambridge to an alcoholic stupor in an outback shanty, gives Adela a manuscript dedicated to her, his muse, for her approval. When Fayle vanishes in the bush Adela is left with the manuscript, which she publishes as her own in London, under the title Gone Under. Soon after this, Chrissy Smith, an honest bush girl whom Fayle had tutored, turns up in Kensington, eager to become an author herself. Chrissy has an "imagination fed on Æschylus and Sophocles, on Virgil and Dante, and the spirit of the Renaissance," but unlike Adela, and unlike Mrs Bearfield in Affinities, her sensibility is undeniably Australian. Her imagination has also been fed by the "strange influence of the Australian Bush" (70). This modification in the cultural inheritance of the heroine is important. In it Praed imagines the possibility of an aesthetic sensibility that can assimilate both metropolitan and colonial experience, and that, crucially, is organically grounded in the landscapes of outback Australia. Adela Goring, now a best-selling author, the embodiment of an "exotic elegance" surrounded with the objets d' art that signify cultural decadence in Praed's work, notices this and sets the girl up with a Remington, employs her as a secretary, and effectively mines her capacity as a writer in order to publish more Australian-themed fiction under her own name. 
The novel is almost completely devoid of the overt Gothicism that we find in Praed's occult fictions. Praed has even tired of describing the decadent interior, which is evoked in the novel in emphatically unrealized prose, rather than through the exhaustively rendered detail of the earlier novels. But it isn't hard to see the trope of vampiric possession transposed into the more quotidian plot that sees the innocent Chrissy sucked dry by an Adela hungry for adulation, wealth and prestige. The name "Goring," the death of her husband, and the sense of her scheming in order to get her hands on aristocratic title no doubt add to this sense of a secularised Gothicism. At one point Adela's book is described as a "backwood's" novel (137), a sharp contrast to the Blackwood's style many of Praed's readers might have come to expect. When Fayle, believed dead, turns up at Hyde Park Corner, Adela's deception is soon revealed, as is the ghost of the novel's title: not just Fayle, the cheated author of a London bestseller, nor Chrissy, but an apparently authentic textual rendering of colonial experience that is misappropriated and purloined for a metropolitan marketplace and hence reconfigured as an alienated product of literary commercialization.

The Ghost is quite clearly a fantasy about the ability of colonial experience to circulate in the metropolis, to side-step or overcome the economies of value - both symbolic and economic - that Esmé Colquhoun represents in Affinities. It is also a text that, at least implicitly, refuses the performativity of aestheticism. In place of this performativity it imagines that texts might be reattached to experiences formed by and grounded in particular, contingent contexts. Here Praed's solution to the problem of an aestheticism that had revealed both its profane, commercial reality and its complicity with imperial hierarchies, was a reinvestment in the notion of place as central to the expressive integrity of the literary text, to the creative process uncompromised by the commercialisation of culture. That this vision would very quickly move beyond national romance and into the realm of channelled writing, in which Praed transcribed Nancy Harward's previous life as a Roman slave, suggests at least one other solution to the problem of the text's materiality as commodity. In Praed's career the frisson of occult-inspired novels would ultimately give way to a more thoroughgoing re-enchantment of textual production in which literature's magical provenance, and hence its claim to distinction, could apparently be assured.

Dartmouth College

\section{NOTES}

1. Kerry Powell has suggested that The Picture of Dorian Gray derives from a species of art novel, which she calls "magic-portrait" fiction, in which paintings motivate or organise both plot and character. See "Tom, Dick and Dorian Gray: Magic-Picture Mania in Late Victorian Fiction." Talia Schaffer has recently mapped the relationship between Ouida's aesthetic novels and Wilde's aestheticism, arguing that the later represents a continuation of Ouida's style and thematic preoccupations. See The Forgotten Female Aesthetes: Literary Culture in Late-Victorian England 150-52. Praed's Affinities and The Soul of Countess Adrian share a great deal with both genres.

2. One result of this, an unintended one no doubt, is that the possibility of a more diverse range of sources is underplayed. The triangulated vampire-plot as Stoker presents it (vampire and male protagonist entering into homoerotic proximity over the soul of their mutual love interest), was rehearsed in at least three of Praed's novels predating Dracula. Stoker's novel carries numerous signs of Praed's 
influence: Renfield's biblical refrain "The blood is the life" (Stoker 141), for instance, echoes in The Brother of the Shadow, in which the vampire is linked to the figure of the "Dugpa," a predatory Eastern magician who "aims only at internal enjoyment, sensuality, the things of the flesh, which red, the blood-colour, typifies. The blood is the life." (69)

3. The letter exists in the extensive Praed Papers, housed in Brisbane's John Oxley Library, State Library of Queensland. See George Bentley to Rosa Praed, 19 January 1885, Praed Papers, 9/4/48 (qtd. in Clarke 83).

4. Praed's Esmé no doubt finds an echo in the Wilde figure, Esmé Amarinth, in Robert Hichens's 1894 The Green Carnation.

5. The phrase is Bourdieu's (see Distinction 4). Needless to say Bourdieu's critique of aesthetic autonomy as an historically constituted mode of cultural capital informs my reading of Praed and of aestheticism more generally. See Bourdieu's The Rules of Art for a fuller account of this paradigm.

6. Mudie's itself would collapse in the 1890 s as a consequence of having to house vast quantities of unread material (see Gagnier 23). It merged with W. H. Smith in 1894. The demise of the tripledecker and corresponding reduction in the importance of the circulating library radically expanded the production runs of popular novels and heralded a more thoroughgoing industrialization of the literary marketplace. N. N. Feltes describes this as the consolidation of "the new patriarchal/capitalist literary mode of production" (128).

7. The tendency to underplay Adorno's account of the relationship between aesthetic autonomy and commodification derives from a take on the Frankfurt School that is overly reliant on Peter Bürger's Theory of the Avant-Garde. Bürger launches an argument about aesthetic autonomy based on Marcuse's notion of "affirmative culture," which is less explicit than Adorno's Aesthetic Theory in its excavation of the commodity-character of autonomous art. For a critique of Marcuse's essay as it pertains to aestheticism, see Psomiades's excellent essay "Beauty's Body: Gender Ideology and British Aestheticism," which explores the "affirmative culture" thesis from the point of view of its persistent elision of gender differences, and offers a provocative reading of the "beautiful woman" as an allegory of the art object as commodity.

\section{WORKS CITED}

Adorno, Theodor W. Aesthetic Theory. Trans. Robert Hullot-Kentor. Minneapolis: U of Minnesota P, 1997. Adorno, Theodor W., and Max Horkheimer. Dialectic of Enlightenment. Trans. John Cumming. New York: Continuum, 1991.

Barlow, Damien. “'My Little Ghost-Slave' the Queer Lives of Rosa Praed.” Australian Literary Studies 17.4 (October 1996): 344-52

Bourdieu, Pierre. Distinction: a Social Critique of the Judgement of Taste. Trans. Richard Nice. Cambridge: Harvard UP, 1984.

- The Rules of Art: Genesis and Structure of the Literary Field. Trans. Susan Emmanuel. Stanford: Stanford UP, 1995.

Bürger, Peter. Theory of the Avant-Garde. Trans. Michael Shaw. Minneapolis: U of Minnesota P, 1984.

Clarke, Patricia. Rosa! Rosa! A Life of Rosa Praed, Novelist and Spiritualist. Carlton: Melbourne UP, 1999.

Corelli, Maria. Wormwood: A Drama of Paris. Ed. Kirsten MacLeod. Peterborough, Ont.: Broadview P, 2004.

Daly, Nicholas. Modernism, Romance and the Fin de Siècle: Popular Fiction and British Culture, 18801914. Cambridge: Cambridge UP, 1999.

Dellamora, Richard ed. Victorian Sexual Dissidence. Chicago: U of Chicago P, 1999.

Dixon, Robert. Writing the Colonial Adventure: Race, Gender and Nation in Anglo-Australian Popular Fiction, 1875-1914. Cambridge: Cambridge UP, 1995.

du Maurier, George. Trilby. London: Penguin, 1995. 
Feltes, N. N. Literary Capital and the Late Victorian Novel. Madison: U of Wisconsin P, 1993.

Ferres, Kay. "Rewriting Desire: Rosa Praed, Theosophy and the Sex Problem." The Time to Write: Australian Women Writers, 1890-1930. Ed. Kay Ferres. Harmondsworth: Penguin Books, 1993. 238-55.

Gagnier, Regenia. Idylls of the Marketplace: Oscar Wilde and the Victorian Public. Stanford: Stanford UP, 1986.

Hichens, Robert Smythe. The Green Carnation. Ed. Stanley Weintraub. Lincoln: U of Nebraska P, 1970.

Marcuse, Herbert. "The Affirmative Character of Culture." Negations: Essays in Critical Theory. Trans. Jeremy J. Shapiro. Boston: Beacon, 1968.

Mason, Stuart. Oscar Wilde: Art and Morality: a Record of the Discussion which Followed the Publication of "Dorina Gray." London 1912.

Powell, Kerry. "Tom, Dick, and Dorian Gray: Magic-Picture Mania in late Victorian Fiction." Philological Quarterly 62.2 (1983): 147-70.

Praed, Rosa. Affinities: a Romance of Today. London: George Routledge and Sons, 1886.

- The Brother of the Shadow: a Mystery of Today. London: George Routledge and Sons, 1886. . Fugitive Anne: A Romance of the Unexplored Bush. London: John Long, 1902.

. The Ghost. London: R. A. Everett, 1902.

Madam Izàn: A Tourist Story. London: Chatto and Windus, 1899.

. My Australian Girlhood: Sketches and Impressions of Bush Life. London: T. Fisher Unwin, 1902.

. The Soul of Countess Adrian: a Romance. London: Trischler, 1891.

Psomiades, Kathy Alexis. "Beauty's Body: Gender Ideology and British Aestheticism.” Victorian Studies 36.1 (Fall 1992): 31-52.

Schaffer, Talia. The Forgotten Female Aesthetes: Literary Culture in Late-Victorian England. Charlottesville: UP of Virginia, 2000.

. "A Wilde Desire Took Me: the Homoerotic History of Dracula." ELH 61.2 (1994): 381-425.

Stoker, Bram. Dracula. Oxford: Oxford UP, 1983.

Wilde, Oscar. The Picture of Dorian Gray. London: Penguin, 1985. 